\title{
Food and Agriculture in 1973
}

\author{
by CLIFTON B. LUTTRELL
}

$\mathbf{R}$ Agriculture have predicted higher food and farm commodity prices for this year and a record realized net farm income of $\$ 21$ billion. The volume of food and farm products is expected to increase somewhat, but demand, both foreign and domestic, is expected to rise even faster, resulting in substantially higher prices. This article summarizes reports given at the 1973 National Agriculture Outlook Conference held in February and in later Department of Agriculture releases, and discusses some of the basic forces underlying the sharp food price increases in late 1972 and early 1973 .

\section{OUTLOOK FOR TOOD}

\section{Prices and Expenditures}

Retail food prices are predicted to average significantly higher this year than in 1972. Most of the average year-to-year increase may have already occurred, however, as food prices have increased sharply in recent months and farm commodity prices have apparently turned down following a steep six-month upswing ending in March. The seasonally adjusted average price of food for home use rose 9.5 percent from October 1972 to March this year. Relatively stable prices, however, are expected to prevail throughout the rest of the year.

While average food prices may not change much during the rest of the year, prices of a number of food items are expected to decline from their current levels. Poultry and egg prices are expected to decline somewhat in the spring months, and pork prices are expected to average lower in the second half of the year than in the first half. Somewhat lower prices are also predicted for fresh fruit and vegetables as the 1973 crop is marketed.

An expected sharp increase in crop production this year will probably not have much immediate impact on the prices of meat and other animal products. A larger feed crop and the elimination of export subsidies will result in lower feed prices, thus providing greater incentive for livestock feeding. In the long run, farmers and ranchers will expand their herds and flocks and produce additional animals for slaughter, milk, and eggs. In the short run, however, the number of animals available for feeding is relatively fixed, and only moderate increases in production of meat and other products per animal are possible.

Food expenditures for home use are expected to increase about 10 percent this year, following a 6 percent increase last year and a trend rate of 5 percent from 1965 to 1972. Total disposable income, however, is expected to rise sharply, and food expenditures as a percent of the total will probably be about the same as a year ago and well below that of earlier years.

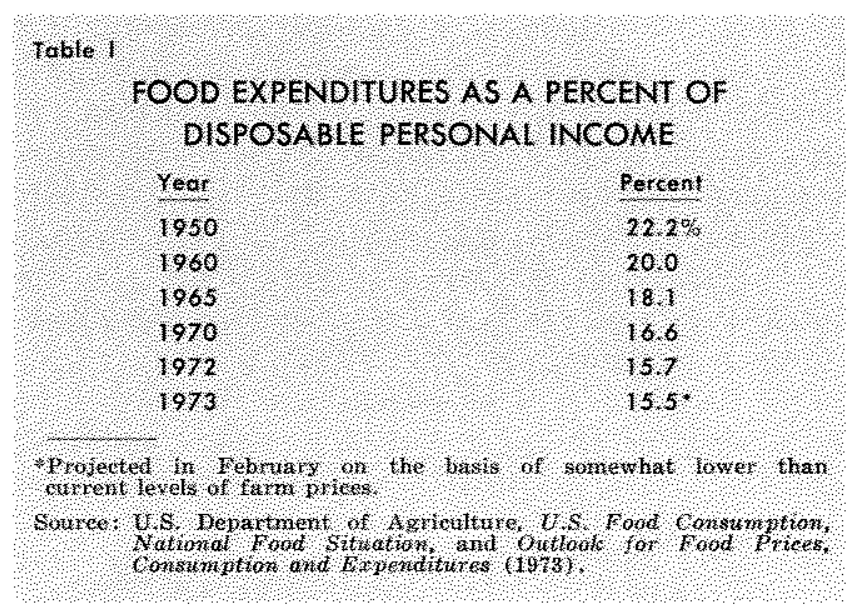

\section{Production and Consumption}

The quantity of food available for domestic use this year is expected to rise somewhat from the 1972 level and new records in total and per capita consumption are likely. Per capita consumption of red meat last year totaled 188 pounds, nearly two percent below the 1971 level. This decline reflected a sharp reduction in pork consumption and a continued downtrend in veal which was only partially offset by small increases in beef, lamb, and mutton (Chart I). Despite the decline, per capita red meat consumption was still higher last year than in any other year except 1971. Red meat consumption, while below year-ago levels in the first quarter, is expected to total 2 or 3 pounds per person more this year than in 1972, with beef accounting for most of the increase. Production is ex. 


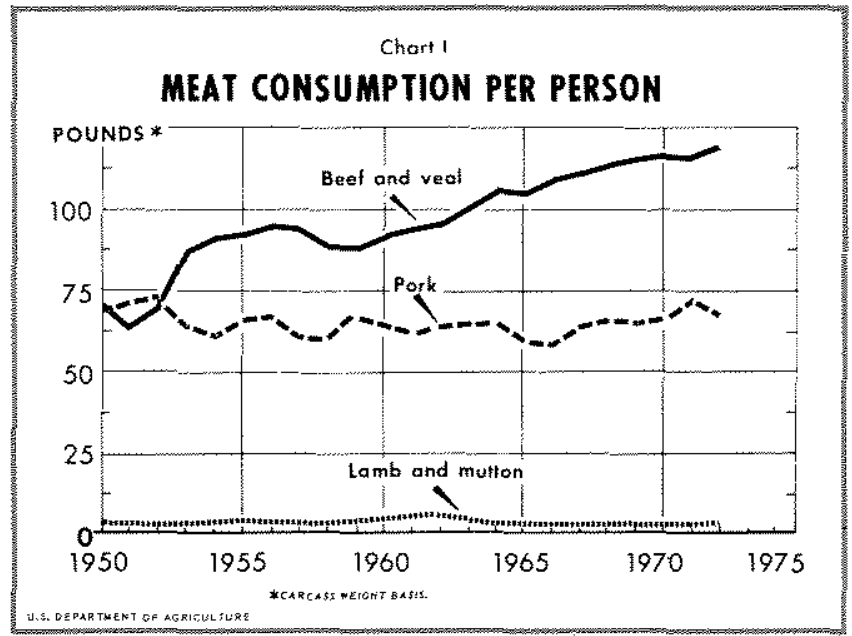

pected to rise moderately. The uptrend has apparently begun and is expected to continue through 1973 . Meat imports may also rise moderately with the removal of most import restraints last year.

Per capita output of poultry is expected to increase as the year progresses, and production of fish and vegetable oils may average somewhat higher than last year. Production of dairy products may be down slightly, however, from the 1972 level, and egg production will likely be down for the second consecutive year. The quantity of fresh fruit and vegetables produced in late 1972 and early 1973 was down from year-earlier levels as a result of unfavorable growing conditions for grapes, pears, tomatoes, and sweet corn. However, as the year progresses the quantity available for consumption will be increasingly determined by 1973 crops which, with normal growing conditions, will likely be larger than a year ago.

\section{OUTMOK TOP AGIICUITUPE}

Farmers are expected to realize about $\$ 21$ billion net income from farming this year, almost 10 percent above that realized in 1972, and far above that for any other year (Chart II). The prospective net income of $\$ 7,500$ per farm is about $\$ 700$ above the 1972 level. Total farm production is expected to be up and farm commodity prices to average at least 5 percent higher than last year (Charts III and IV). Realized gross income is projected to rise 11 percent to $\$ 74$ billion (Table II). Cash receipts from farm commodity sales are expected to total more than $\$ 67$ billion, about 15 percent above the 1972 level, but direct Government payments are expected to decline about $\$ 1$ billion from last year as a result of reduced payments under the feed grain program. A sharp increase in production expenses is anticipated, however, which will partially offset the realized gross income gain.

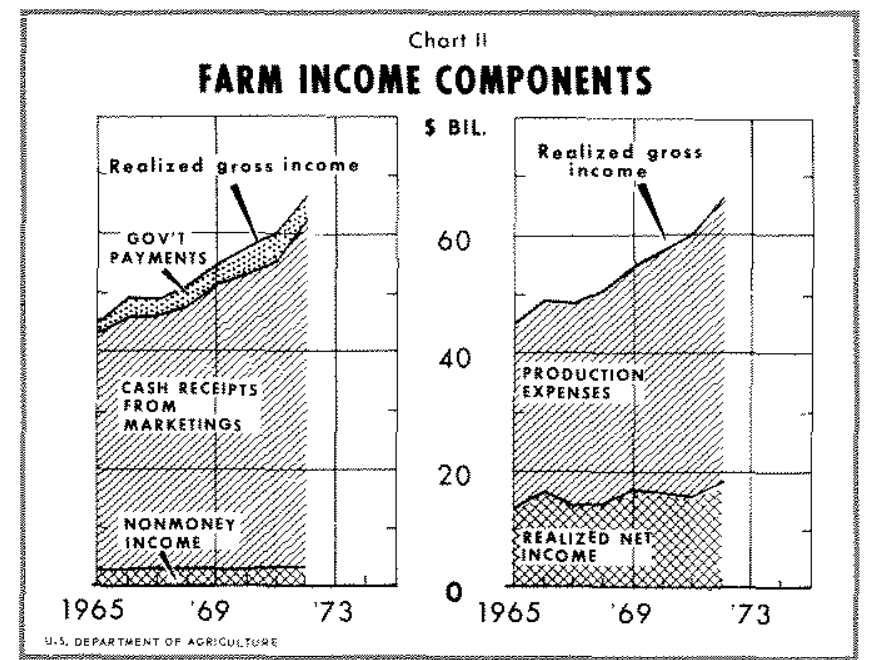

The volume of livestock and livestock products marketed this year may rise slightly while prices received for these products are expected to average significantly higher than last year. Crop production controls have been relaxed and the volume of crops marketed is expected to rise sharply. With rising de mand for crops both here and abroad, crop prices may still average significantly higher than in 1972 .

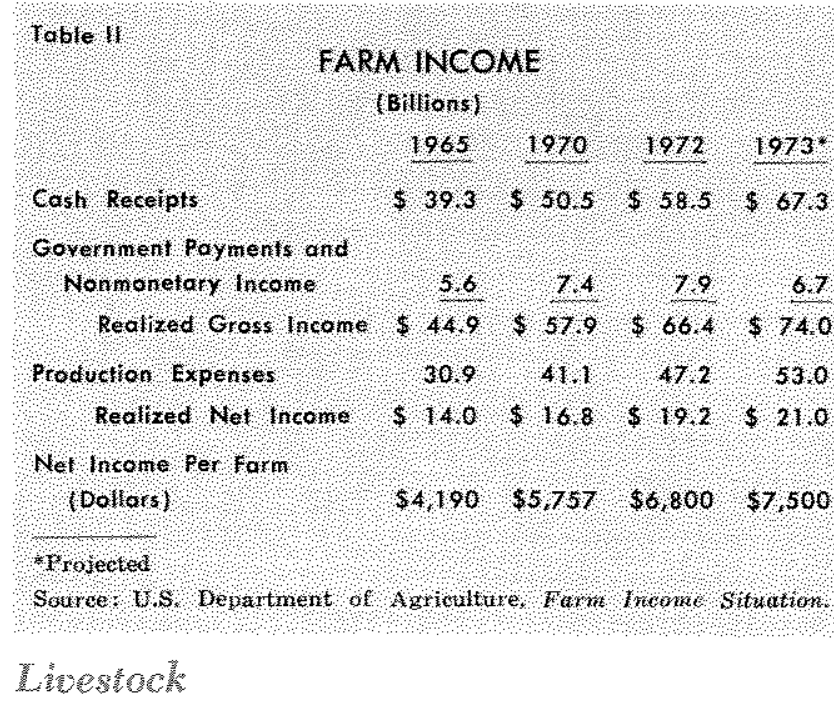

Livestock and livestock product sales are expected to total $\$ 5$ billion more this year than in 1972. Farmers are expected to market a few more cattle and about the same number of hogs at higher prices. Output of dairy products may be down slightly, but the decline will be more than offset by higher prices resulting in somewhat higher gross receipts for dairy farmers. Broiler chick replacements in recent months have been lower than a year earlier, and broiler production will be somewhat less during the spring months. Production is expected to rise to year-earlier levels during the summer, and prices for 1973 will average 


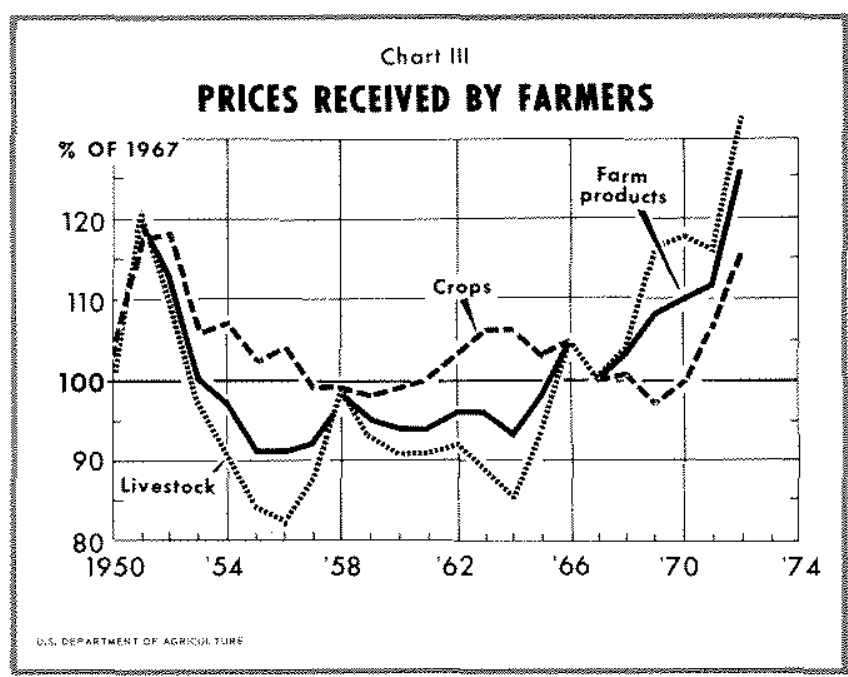

somewhat higher than last year. Egg production is predicted to be moderately less than a year ago as a result of a substantial decline in the laying Hock last year. The size of the laying flock is expected to increase as the year progresses, and egg production to approach 1972 levels near the end of the year. Egg prices for 1973 are expected to average well above year-ago levels, and cash receipts from egg sales will be somewhat larger.

\section{Crops}

Crop receipts are forecast at almost $\$ 4$ billion higher than a year ago, with both prices and volume of marketings up significantly. Production controls have been relaxed and with the incentive provided by higher prices, farmers have indicated that they intend to plant 8 percent more acres to major crops. Major increases in production are in prospect for feed grain, food grain, and soybeans."

On March 1 farmers indicated plans for planting 6.5 million more acres of feed grain this year than a year ago, an increase of 6 percent. The quantity of feed grain available in the current marketing year is somewhat greater than a year ago despite the smaller 1972 crop." The 1972 crop plus carryover stocks at the beginning of last year's harvest season totaled 246.4 million tons -5 million tons above the year-ago level. However, domestic and foreign usage of U.S. feed grain is expected to total 210 million tons -17 million more than a year ago - and carryover into next year may be down to about 36 million tons 10 million less than a year ago.

1 Feed grains inchude com, grain sorghum, oats, and barley. Food grains include wheat and rice.

2The current marketing year for each crop began with the harvest season for the 1972 crop. For example, the cimrent marketing year for corn began October $1,1972$.

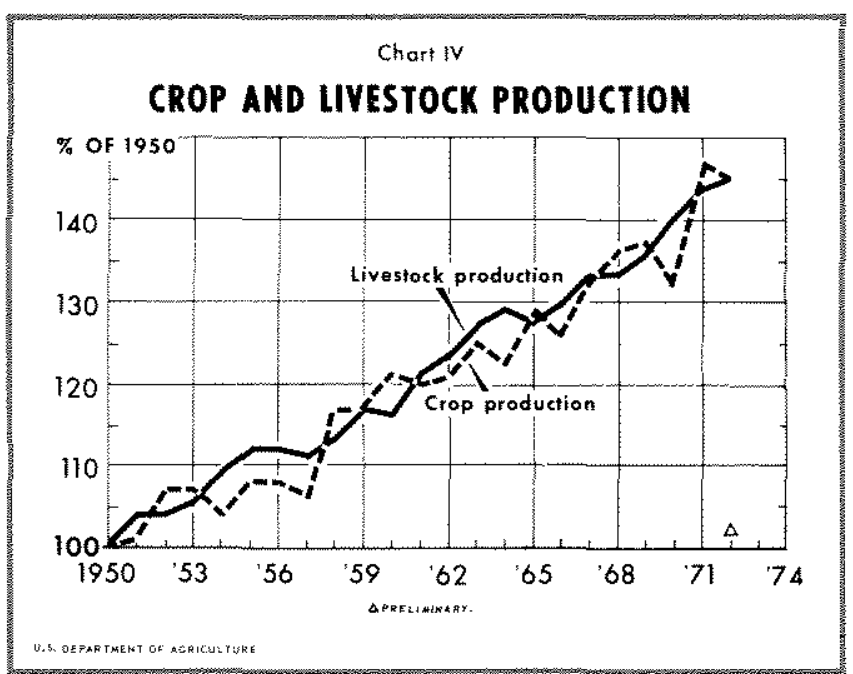

Government stocks of feed grains are almost exhausted. Domestic use this year is expected to total 177 million tons, up 7 percent from a year ago and exports will be up about 22 percent to 33 million tons. Reduced grain production in the Soviet Union, Mexico, India, and Mainland China and sustained growth of demand in Japan and Western Europe account for most of the increased exports. Prices of feed grains have risen sharply since October and are expected to remain well above 1972 levels during the current marketing year.

Food grain acreage is expected to increase about 6 percent to 60.2 million acres this year. Wheat plantings, which account for most of the food grains, are expected to total 58.2 million acres. If normal weather conditions prevail, production of wheat is expected to exceed the 1,545 million bushels last year by about 12 percent.

Production plus carryover stocks of wheat in 1972 totaled 2,409 million bushels, the largest quantity available for utilization in any marketing year since 1962-63. Utilization, however, appears headed for a record 1,968 million bushels, 23 percent above the previous peak, as a result of a sharp increase in export demand. Exports are predicted to total 1,150 million bushels, a third more than the previous record. Larger sales than previously have been made to those nations which regularly import U.S. wheat. In addition, the USSR has purchased about 400 million bushels, and some purchases have been made this year by the People's Republic of China. Nearly all the Govern. ment-held inventory of wheat may be exhausted by the close of the current marketing season on July 1.

The rise in wheat prices during the past marketing year was the sharpest on record - from $\$ 1.32$ per bushel last July to $\$ 2.38$ in January. Prices had de- 
clined somewhat in April and some further decline is expected as the harvesting season approaches, but prices will probably remain 40 to 50 cents above the Government price support level of $\$ 1.25$ per bushel.

The rice acreage allotment has been raised 10 percent this year in anticipation of strong world demand, and on March 1 growers indicated plans for an equal increase in acreage seeded. Rice utilization is expected to exceed the 1972 crop of 85.2 million cwt., resulting in an August 1, 1973 carryover well below the levels of recent years. Prices for the season are likely to average more than a collar above the loan rate of $\$ 5.27$ per cwt.

Soybean plantings, on the basis of farmers' indicated plans on March 1, will exceed the 1972 acreage by 14 percent. With normal yields, production will exceed 1.5 billion bushels, up 17 percent from a year ago. The 1972 crop plus carryover stocks totaled 1.35 billion bushels, 6 percent above the year-earlier total despite some weather damage to the crop during harvest season. However, substantially higher usage is forecast for this year and carryover stocks this fall may not exceed 60 million bushels. Domestic crushings of soybeans are forecast to increase about 4 percent from last year to 750 million bushels, and exports are forecast to rise more than 14 percent to 475 million bushels.

Chief factors contributing to the sharp increase in soybean exports are a world shortage of high-protein feeds stemming from reduced Peruvian fish meal production and a general expansion of livestock feeding in Western Europe, the Soviet Union, and Japan. The output of animal products is rising throughout the world and soybean meal is a leading source of protein for animal feed. Prices of soybeans have advanced sharply in recent months - from $\$ 3.30$ per bushel in October to about $\$ 6.00$ in mid-April - and the price paid farmers for the 1972 crop may average about $\$ 4$ per bushel, $-\$ 1$ per bushel higher than for the 1971 crop.

Tobacco production is forecast at 8 percent above year-earlier levels. Surplus stocks of flue-cured tobacco in the current marketing year have been reduced, and basic marketing quotas for the 1973 crop have been increased. The burley tobacco stocks, however, are up somewhat and the marketing quotas are slightly less than last year. Government price supports, which largely determine the prices received by farmers, will be up 5.3 percent, and gross returns to farmers should be significantly higher than a year ago.

Cotton production this year is projected to be somewhat less than the relatively large 13.6 million bale crop of 1972 . The national base acreage allotment for 1973 was reduced 13 percent, but tarmers in early March indicated plans to plant 13.1 million acres, somewhat more than the allotment, and only 7 percent less than in 1972. Production is expected to decline to about 12.2 milion bales, 11 percent less than a year earlier. The large 1972 crop boosted cotton inventories, and the carryover on August 1 this year may total about 4.75 million bales, up from last year's 20 year low of 3.4 million. Exports in the current marketing year are expected to total about 4.5 million bales, up from 3.3 million last year, but domestic mill consumption may decline about 5 percent to $7.8 \mathrm{mil}$ lion bales, the smallest since $1948-49$. The use of manmade fibers continues to expand both here and abroad at the expense of cotton. The relative proportions of cotton and man-made fibers in total fiber use in the U.S. have reversed during the past twelve years. Use of man-made fibers rose from less than one-third the total in 1960 to almost two-thirds the total in 1972 , while use of cotton in this period declined from almost two-thirds to one-third of the total. Cotton prices have increased sharply since last October, but in midApril they were still below year-ago levels.

\section{BAST SUPPL AND DEMAND FORCES}

From October 1972 to March 1973 wholesale farm commodity prices and retail prices of food used at home rose at annual rates of 82 and 24 percent, respectively. ${ }^{4}$ In comparison, these prices rose only 2.8 and 2.6 percent per year, respectively, from 1955 to March 1973. Furthermore, since 1955 all consumer expenditure items less food have increased at a 2.7 percent annual rate. Of the major consumer expenditure groups, which include food, housing, apparel and upkeep, transportation, and health and recreation, only transportation and apparel and upkeep have increased at a slower rate than food during this period (Table III). Only since 1970 have food prices increased faster than the other categories, and a major portion of this increase occurred during the past year.

Despite this slower trend growth rate in food prices, the recent sharp increases have been accompanied by protests, demonstrations, parades, and a national meat boycott. Famers, meat packers, wholesalers, and supermarkets have all been blamed for the higher food costs. In consequence, President Nixon in late March imposed price ceilings on beef, pork, and lamb. The ceilings were set at the highest price received for

Bales of 480 pounds net weight.

tThese rates do not reflect long-serm trends because of the volatile nature of fann commodity prices. 


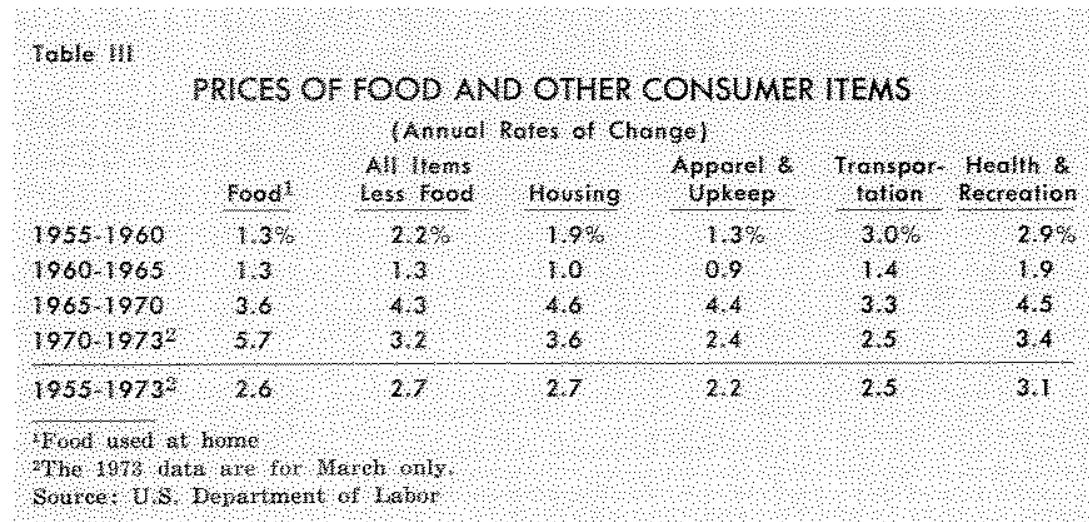

Additional factors contributing to the food price increases were adverse weather conditions and the downswing phase of the hog cycle. Unfavorable autumn and winter weather contributed to somewhat smaller than anticipated feed and soybean crops and a smaller quantity of fresh fruit than was produced a year earlier. The hog production cycle was on the downswing last fall in response to low profits in pork production in late 1970 and 1971. Pork production per capita declined about 12 percent from the thind quarter of 1971 to the third quarter of 1972 , a major factor in the 2 percent reduction in all livestock products.

At current price and output levels, however, the food industry will increase its productive capacity. Farmers have already made plans for increased production. Output of farm products will tend to expand as farmers expand crop acreage, breeding herds, flocks, and other inputs. Prices of farm products declined somewhat from mid-March to mid-April after rising at an annual rate of 54 percent during the previous six months. They are expected to decline further as larger quantities of farm products are marketed late this year and in 1974 .

Food prices, however, are not likely to decline much this year despite some possible decline in prices paid to farmers. It is questionable whether all the increase in farm commodity prices has as yet been reflected in retail food prices. If not, some further rises in retail food costs are in prospect as a result of the lagged effects of the farm commodity price increases. There are also other factors which will tend to prevent a major reduction in food prices this year, such as rising real income and population, and increased use of Govemment food stamps and other food subsidies. In addition, costs of domestic food production tend to rise during a period of general inflation. Furthermore, rising world demand for food and livestock feed is expected. These factors tending to increase food prices may offset, at least through 1973, most of the increased production stimulated by the higher prices. ${ }^{3}$

If there is a sharp increase in crops produced and sufficient price incentive after the fall harvests for farmers to expand livestock production, food prices

\footnotetext{
"For a more thorough discussion of most of these factors, see Clifton B. Luttrell, "Meat Prices - Too High or About Right?"
} this Review (October 1972). 
may decline in 1974. Part of the upward pressure on prices will be offset by the reduction of Government restrictions on crop production, the relaxation of import restrictions, the elimination of export subsidies, technological change, and perhaps some decline in foreign demand for domestic livestock feed.

\section{SUMNAAT}

In summation, food supplies per capita are projected to be larger, and average food prices and expenditures for food substantially higher this year than a year ago. However, disposable personal income is expected to rise sharply again this year, resulting in consumers spending about the same percent of their income on food.

Gross farm income is expected to be significantly higher this year than a year ago, reflecting both increased output and higher average prices for farm products, but somewhat lower Government payments to farmers. A sharp increase is predicted for farm production expenses; however, total realized net income is projected to be well above the year-ago level. Furthermore, the total will be shared by fewer farm operators as some further decline in number of farms is anticipated.

The sharp increase in food and farm product prices during the late fall and winter months of 1972-73 largely reflected short-run supply and demand forces such as the unfavorable harvesting season, a cyclical downturn in hog production, and an unexpectedly large increase in export demand for feed grain and protein supplements. Farmers are responding to the higher prices by planned increases in production. As production of farm products and food rises, prices may decline from current levels.

Food prices, however, are not likely to decline much this year as a result of the lagged effects of the recent sharp increases in farm commodity prices. In addition, rising population and incomes, Government food subsidies, and general inflation will tend to increase demand for food and prevent a major price decline despite the somewhat higher production anticipated. Food prices are expected to level off in the late spring and remain fairly stable for the rest of the year and if larger crops this fall result in lower feed prices and further expansion of livestock production, some decline in food prices from current levels is likely next year.

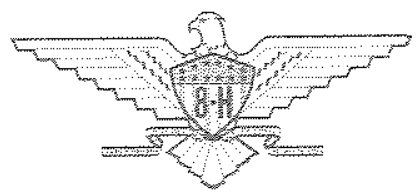

